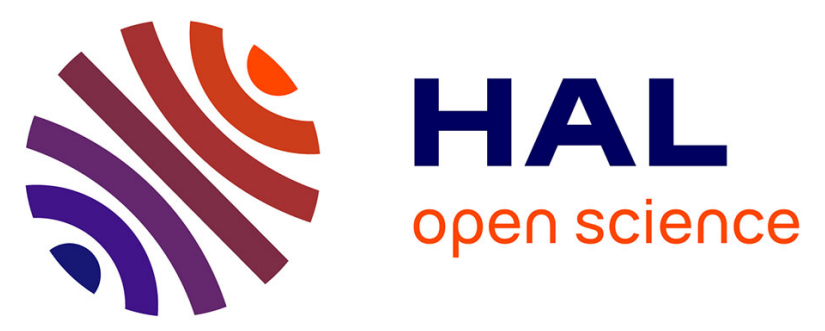

\title{
3D models related to the publication: New middle Eocene proboscidean from Togo illuminates the early evolution of the elephantiform-like dental pattern
}

Lionel Hautier, Rodolphe Tabuce, Koffi Evenyon Kassegne, Yawovi Zikpi, Mickaël Mourlam, Maëva Orliac, Frédéric Quillévéré, Anne-Lise Charruault, Christophe Johnson, Guillaume Guinot

\section{To cite this version:}

Lionel Hautier, Rodolphe Tabuce, Koffi Evenyon Kassegne, Yawovi Zikpi, Mickaël Mourlam, et al.. 3D models related to the publication: New middle Eocene proboscidean from Togo illuminates the early evolution of the elephantiform-like dental pattern. MorphoMuseum, 2021, 10.18563/journal.m3.145 . hal-03423343

\section{HAL Id: hal-03423343 \\ https://hal.science/hal-03423343}

Submitted on 18 Nov 2021

HAL is a multi-disciplinary open access archive for the deposit and dissemination of scientific research documents, whether they are published or not. The documents may come from teaching and research institutions in France or abroad, or from public or private research centers.
L'archive ouverte pluridisciplinaire HAL, est destinée au dépôt et à la diffusion de documents scientifiques de niveau recherche, publiés ou non, émanant des établissements d'enseignement et de recherche français ou étrangers, des laboratoires publics ou privés. 


\title{
3D models related to the publication: New middle Eocene proboscidean from Togo illuminates the early evolution of the elephantiform-like dental pattern.
}

\author{
Lionel Hautier $^{1 *}$, Rodolphe Tabuce ${ }^{1}$, Koffi Evenyon Kassegne ${ }^{2}$, Yawovi Zikpi Amoudji ${ }^{2}$, Mickaël Mourlam ${ }^{1}$, Maëva \\ Orliac $^{1}$, Frédéric Quillévéré ${ }^{3}$, Anne-Lise Charruault ${ }^{1}$, Ampah Kodjo Christophe Johnson $^{2 *}$, Guillaume Guinot ${ }^{1}$ \\ ${ }^{1}$ Institut des Sciences de l'Evolution de Montpellier, Université Montpellier, CNRS, IRD, Cc 064; place Eugène Bataillon, 34095 Montpellier Cedex 5, \\ France; email: lionel.hautier@umontpellier.fr. \\ ${ }^{2}$ Département de Géologie, Faculté des Sciences, Université de Lomé, B.P. 1515 Lomé, Togo. \\ ${ }^{3}$ Univ Lyon, Université Claude Bernard Lyon 1, ENS de Lyon, CNRS, UMR 5276 LGL-TPE, F-69622 Villeurbanne, France. \\ *Corresponding authors: Dr. Lionel Hautier lionel.hautier@umontpellier.fr and Dr. Christophe Johnson christophe_johnson@yahoo.fr
}

\begin{abstract}
This contribution contains the 3D models described and figured in the following publication: Hautier $L$, Tabuce R, Kassegne KE, Amoudji YZ, Mourlam M, Orliac M, Quillévéré F, Charruault A-L, Johnson AKC, Guinot G. 2021. New middle Eocene proboscidean from Togo illuminates the early evolution of the elephantiform-like dental pattern.
\end{abstract}

Keywords: Comparative anatomy, Middle Eocene, Molar, Proboscidea, Togo

Submitted:2021-05-21, published online:2021-10-28. https://doi.org/10.18563/journal.m3.145

Inv nr. (model Id)

ULDG-DAG1(M3\#769)

ULDG-DAG1(M3\#771)

\author{
Description \\ 3D surfaces of the dentine and \\ enamel. \\ $\mu \mathrm{CT}$ scan of the molar \\ (resolution: $47.6 \mu \mathrm{m}$ )
}

Table 1. 3D data representing the specimen ULDG-DAG1 (Dagbatitherium tassyi). Collection: University of Lomé, Togo.

\section{INTRODUCTION}

We present here the 3D model of a proboscidean specimen discovered in middle Eocene phosphate deposits from Dagbati (Togo) and belonging to a new genus and species, Dagbatitherium tassyi (Hautier et al., 2021; see Table 1 and Fig. 1). Dagbatitherium displays several elephantiform dental characteristics such as a three-layered Schmelzmuster, the presence of a mesoconid, transversely enlarged buccal cusps, and the individualization of a third lophid associated to a minute distal cingulid. This new proboscidean taxon potentially represents the oldest record of the Elephantiformes and bridges a critical temporal and morphological gap in the proboscidean fossil record (Hautier et al., 2021). A 3D model of the enamel cap and dentine was reconstructed in order to reveal hidden anatomical features and characterize differences in enamel thickness.

\section{METHODS}

The molar ULDG-DAG1 was imaged using high-resolution microtomography $(\mu \mathrm{CT})$ at the MRI platform of the Institut des Sciences de l'Evolution de Montpellier (ISE-M). The scan resolution was $23.8 \mu \mathrm{m}$. Image segmentation of the cranium elements was performed on the $\mu \mathrm{CT}$ images with Avizo Lite 2019.4 (Thermofisher Scientific) software using the segmentation threshold selection tool. The 3D virtual restoration was performed with MorphoDig software (v. 1.5.3; Lebrun, 2018). The 3D surface model of the molar ULDG-DAG1 is provided in
VTK polydata format, and can therefore be opened with a wide range of freeware.

\section{ACKNOWLEDGEMENTS}

We thank the Department of Geology of the University of Lomé and all members of the PaleonTogo project, especially Jérémy Martin (University of Lyon), Kodjo Adika Togbe and Pauline Da Costa (University of Lomé). We also warmly thank M. Abalo Kézié, general director of SNPT, as well as employees from these companies, M. Bikiliniwé Ekpao, M. Kudzo D'Almeida, M. Adodo Goe Akue, M. Mazama-Esso Bidabi, M. Laba Minza, M. Sizing Adom, M. Kossi Karim and M. Fan-Name Kanfeli, for providing access and sampling permissions. We are also very grateful to Emmanuel Robert (Laboratoire de Géologie de Lyon, France) who provided access to material of Palaeomastodon. 3D data acquisition was performed using the $\mu \mathrm{CT}$ facilities of the MRI platform member of the national infrastructure France-Bio Imaging supported by the French National Research Agency (ANR-10-INBS-04, 'Investments for the future') and of the Labex CEMEB (ANR-10-LABX-0004) and NUMEV (ANR10-LABX-0020). This study is part of the PaleonTogo project, which is partly supported by a CNRS PICS grant (n8229424) and the National Geographic Society (grant NGS-72222R-20).

\section{BIBLIOGRAPHY}

Hautier L, Tabuce R, Kassegne KE, Amoudji YZ, Mourlam M, Orliac M, Quillévéré F, Charruault A-L, Johnson AKC, Guinot G. 2021. New middle Eocene proboscidean from Togo illuminates the early evolution of the elephantiform-like dental pattern. Proceedings of the Royal Society B. https://doi.org/10. 1098/rspb.2021.1439 

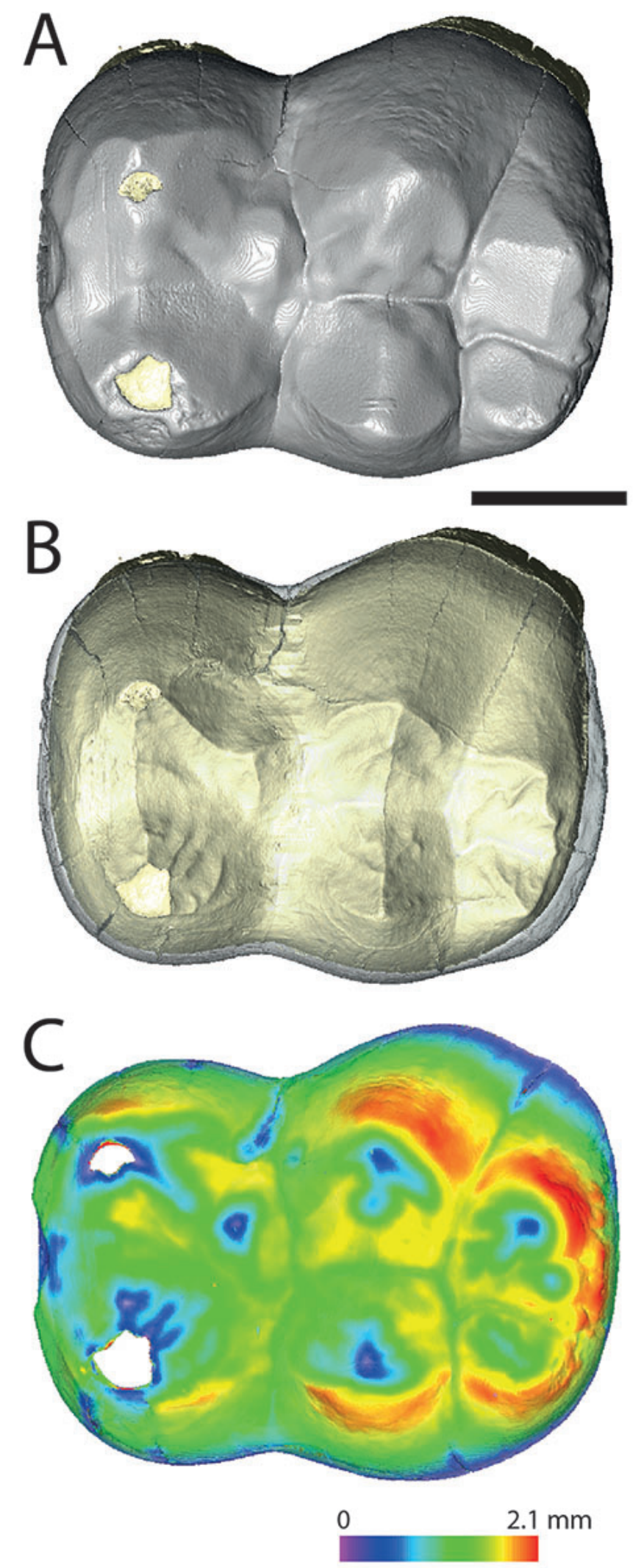

Figure 1. 3D reconstructions of the molar ULDG-DAG1. A and B, occlusal views; the enamel is in grey, the dentine in yellow. C, 3D enamel thickness distribution maps with spectral colors. The thickest enamel is represented in red, the thinnest enamel is represented in dark blue. Color scale: 0-2.1 mm. Scale bar represents $1 \mathrm{~cm}$. 